\title{
The role of human capital and collaboration with academia for innovation in hospitality sector: the case of Mugla
}

\author{
Ummuhan Gökovalı ${ }^{\mathrm{i}}$ \\ Mehmet Avcı ii
}

Muğla University (Turkey)

\begin{abstract}
The relevance of human capital and collaboration with academia for innovation in the hospitality sector has never been denied, but the empirical evidence for this link is inadequate as far as Turkey is concerned. This paper intends to contribute to the knowledge in this area by employing self generated survey data for the province of Mugla, which is one of the most attractive holiday destinations in Turkey. The aim of this paper is to investigate the effects of human capital and collaboration with academia on innovation performance of hospitality firms. The results of the survey data and empirical investigation of logit and probit econometric models indicate that these factors are indeed conducive factors for the innovation performance of hospitality firms.
\end{abstract}

Keywords: Innovation in Tourism; Determinant factors of innovation; Human capital; Collaboration with academia.

Título: El papel del capital humano y la colaboración con las universidades en la innovación del sector de hostelería: el caso de Mugla

Resumen: La literatura no niega la relevancia del capital humano y la colaboración con las universidades en vistas a la innovación en el sector de hostelería, pero la evidencia empírica de este enlace es insuficiente por lo que se refiere a Turquía. Este trabajo pretende contribuir al conocimiento en esta área mediante el empleo de datos generados a través de una encuesta hecha en la provincia de Mugla, uno de los destinos turísticos más atractivos de Turquía. El objetivo de este trabajo es investigar los efectos del capital humano y la colaboración con instituciones académicas en el nivel de innovación de las empresas de hostelería. Los resultados de los datos del estudio y la investigación empírica de los modelos logit y probit econométricos indican que estos factores son realmente los que propician la innovación en las empresas de hostelería.

Palabras clave: Innovación en turismo; Factores determinantes de la innovación; Capital humano; Colaboración con la academia.

i Mugla University Department of Economics, Kotekli, Mugla, Turkey, ummuhan@mu.edu.tr. ii Mugla University Department of Economics, Kotekli, Mugla, Turkey, mehmeta@mu.edu.tr. 


\section{Introduction}

As in manufacturing sectors, economic performance, survival and competitiveness of hospitality firms depend on their innovation capabilities and how quickly they adopt new technologies in their management and organizational structure, and in their accommodation and services facilities. The recognized importance of innovation led to the surge of research and this topic was investigated intensively from different perspectives. While, the vast majority of studies focus on manufacturing industries, there is small amount of research related to innovation in the service sector and even less in the hospitality sector.

Although innovation in the hospitality sector lately attracts scholars in terms of the type of innovation, the determinant factors and the outcome effects of innovation, there are few studies that specifically take into account the investment into $\mathrm{hu}^{-}$ man capital and collaboration with the university as determinant factors of innovative activities of hospitality firms. These studies are limited around the world and very scarce in Turkey. As far as we know, there is no study which specifically deals with the relationship between innovation capabilities and investment into human capital and collaboration with the university of hospitality firms in Turkey.

Given the lack of academic empirical research for the link between innovative behaviors and investment in to human capital and collaboration with the university of hospitality firms in Turkey, this paper intends to contribute to the knowledge in this area by employing self-generated survey data for the district of Mugla, which is the second largest tourist destination (both for national and international tourists) in Turkey. The main purpose of this study is to lay out innovative capabilities of hospitality sector in the district of Mugla and empirically compare and contrast similarities and differences among hospitality firms in terms of innovation capabilities and investment in to human capital and cooperation with the academia. For this purpose, the second section surveys the literature on the role of human capital and collaboration with academia for hospitality firms, while section three summarizes the main findings of the questionnaire. Section four employs logit and probit econometrics models to determine the factors that affect innovation capabilities of hospitality firms. The last section is reserved for concluding remarks.

\section{Literature survey}

Innovation studies go back to Schumpeter's (1934) analysis. Since then, both theoretical and empirical contributions have been done into innovation studies. Although Schumpeter's analysis was mainly applied to the manufacturing sector, and innovation studies are still largely dominated by manufacturing both in terms of the theory and empirical analysis, innovation studies in the service sector have also been developed (among others see, Barras, 1986; Sundbo, 1997; Sirilli and Evangelista, 1998; Hughes and Wood, 2000; Drejer 2004; Tamura et al., 2005). Hence the innovation approach developed originally for the manufacturing sector can still be used to analyze services (Sundbo, 1997; Sirilli and Evangelista, 1998; Hughes and Wood, 2000). However, service and manufacturing firms differ from each other in terms of $i^{-}$) the utilization of intellectual property rights and existence of research and development department (Sundbo, 1997, Tamura et al., 2005), ii-) the types of innovation (Sundbo, 1998), iii-) differences in responsiveness to markets, low technology content of the service (tourism) sector (Hjalager, 2002; Decelle, 2006) and iv-) non-existence of university-business collaborations in the service (tourism) sector (Hjalager, 2002).

Innovation analysis in the tourism sector can be analyzed similarly to that of the service sector. There are several classifications of innovations in the tourism sector (for more detailed information see among others Decelle, 2006; Hjalager, 1997; 2002; Jacob and Groizard, 2007). Innovations in tourism can be behavioral and technological or a mixture of them. Weiermair (2006) distinguishes three factors behind the innovation in tourism. These are supply or supply-related determinants (for example new technologies requiring development of new skills, services or form of organizations in tourism such as the development of e-tourism, and e-marketing in tourism), demand drivers (social and economic factors such as flexible working time, more income and increased value of holidays) and the level and pace of competition (globalization and deregulation increased competition and lead to process innovation) (p. 60).

Hjalager (2010) distinguishes three theoretical schools in explaining the determinants and driving forces of innovation in tourism. The first one is the Schumpeterian school where entrepreneurship is viewed as a driving force in innovation behavior. The second one is the technology-push/demand-pull 
paradigm in which both concepts have some effects on the innovation performance of tourism firms. The third one is the Marshalian innovation systems or innovation cluster approach. However, Hjalager (2010) concludes that "there is a lack of comprehensive empirical evidence to document the nature of driving forces in innovation systems" (p. 5).

There are a small number of studies which specifically dealt with the innovation in the hospitality sector. These studies are mostly concentrated on the type of innovation within the hospitality sector. In these studies process innovations are found to be more important than product innovations (Jacob et al., 2003; Blake et al., 2006; Jacob and Groizard, 2007). Product innovations are limited in the tourism sector because tourism mainly depends on the natural and manmade attractions of the destination, hence limiting the potential for product innovations (Keller, 2006).

In terms of the technological area where technological innovations take place, the ICT area followed by environmental innovations and the security area constitute the largest part in the Latin American (Mexico and Dominican Republic) chain (Balearic) hotels (Jacob and Groizard, 2007). This picture is similar to those found for the Balearic Islands (Orfila-Sintes et al., 2005) except that a more innovative behavior is found in kitchen and restaurant equipment after the ICT area. The use of technologies usually embodied in new machinery, equipment and software is the dominant innovation form in the hospitality sector in the Balearic Islands (OrfilaSintes et al., 2005).

There are several factors that affect innovation behavior of hospitality firms, such as proximity and clustering, thus facilitating knowledge spillovers. Clustering with returns to scale factors can make a region competitive in terms of provision of well educated and trained personnel and infrastructure (Decelle, 2006). The other important factor is the utilization of information and communication technologies in tourism (Keller, 2006). Adaptation of information and communication technology and efficient usage of these technologies are very important factors for the development of the tourism sector as well as for the sustainability of medium and small sized firms.

Some others investigated the effects of innovation on hotel performance and found a positive relationship (Blake et al., 2006; Orfila-Sintes and Mattsson, 2009), while others investigated the determinant factors of innovation in the hospitality sector. The hotels which use professional management instruments and information technologies (Sundbo et al, 2007) and those which develop group and project management skills, and learning culture (Kumar et al., 2008) are more innovative compared to others. Moreover, hotels which belong to chain, under management contract and managed in lease properties are more innovative than hotels operating independently or managed by the owners (Orfila-Sintes et al., 2005; Sundbo et al., 2007). Hotels are found to be more innovative as the tour operators' importance in booking (Orfila-Sintes et al., 2005; Sundbo et al., 2007) and the occupancy rate increase (OrfilaSintes et al., 2005). Further, more than half of noninnovating firms are contracted under a half-board regime, while the customers of $53.5 \%$ of innovators use full board or all-inclusive systems (Orfila-Sintes et al., 2005).

Firm size and innovation behavior are the other researched areas within innovation studies in the accommodation sector. Firms tend to be more innovative as their size and/or scale or range of activities increase (Hjalager, 2002; Jacob et al., 2003; Jacob and Groizard, 2007; Sundbo et al., 2007). 3 and 4-5 star hotels are found to be more innovative, and innovative behavior of 1 and 2 star hotels include the use of computer facilities and hardware (Orfila-Sintes et al., 2005).

The level of human capital and investment into human capital is another key element in innovation capabilities of firms. Employee training for the Taiwanese hotel industry (Chun-Yao et al, 2008) and for independent hotels in Germany (Ottenbacher et al., 2006) is found to be one of the important determinant factors for innovation.

Firms' age can be another important factor for the innovation performance of companies. However, its effect on innovation is ambiguous. While young firms are expected to be more innovative than their older counterparts due to less resistance to innovative ideas, one can also expect just the opposite relation between the firms' age and innovative behavior. As firms' age increases the innovation capabilities increase as well due to firms' learning-by doing, an established name and reputation and continuous improvements in their facilities (Pires et al., 2008).

\section{Innovation In Hospitality Firms In Mugla Dis- trict}

There is no available data concerning the innovative activities of hospitality firms for Turkey in 
general and for Mugla in particular. In this study self-generated survey data is employed to investigate the role of human capital and collaboration with academia on innovation capabilities of hospitality firms. All hotels which have stars from 1 to 5 and holiday villages (first and second class) around the Mugla district are the target population and the survey methodology is personnel interview at the hotels. The list of hotels was accessed from the tourism office of the Mugla district. There are 331 hotels which are categorized by star including holiday villages. Of these 200 hotels were contacted and 137 of them participated in the interview and answered the questionnaire, which was previously tested using a pilot study and revised according to the feedback received.

Table 1 presents the descriptive statistics of the questionnaire results. According to the survey results, $42.34 \%$ of hotels are innovative, whereas $57.66 \%$ of the hotels are not innovative ${ }^{2}$. Within the innovating firms, a higher percentage of firms hires a professional manager, have some kind of certifications (these certifications include HACCP, Environmental Management Standards, Service Compliance Certificate, and other certifications), and trained their employees. In terms of average employee, investment and occupancy rate, innovating firms outperform the non-innovating firms.

Further, innovating firms collaborate with academia more frequently than non-innovating firms. Small-sized firms are dominant in the hospitality sector, followed by medium and big-sized firms. Most of the innovating firms are medium sized whereas most of the non-innovating firms are small-sized. According to the survey results, innovative activity seems to increase as firm size increases. As far as the age of the firm is concerned, survey results indicate that the average age of innovating firms is higher than that of non-innovating firms.

\section{Model and results}

Our model is estimated by logit and probit estimation methods. Our dependent variable takes the value of 1 if the firm innovates and 0 otherwise. Four sets of independent variables are of special interest to this study. These are collaboration with academia, firms' size, firms' capital and labor characteristics. Collaboration with academia takes the value 1 if the firm collaborates with the academia, zero otherwise. Size is measured by the number of employees following Sundbo et al. (2007). To allow the non-linear size effects we also include the size square in our estimation. Capital and labor characteristics include variables such as investment (the share of investment in income), professional management (dummy variable taking one if the hotel is managed by a professional manager and zero otherwise), yearly occupancy rate, non-certified (dummy variable taking one if the hotel does not have any certification and zero otherwise), training of employees (dummy variable taking one if training program is utilized

\begin{tabular}{|c|c|c|c|c|}
\hline & \multicolumn{2}{|c|}{$\begin{array}{c}\text { Innovating Firms } \\
(58-\% \text { 42.34) }\end{array}$} & \multicolumn{2}{|c|}{$\begin{array}{c}\text { Non- Innovating Firms } \\
(79-\% 57.66)\end{array}$} \\
\hline & Number & $\%$ & Number & $\%$ \\
\hline Professional Manager & 54 & 93.10 & 6 & 7,60 \\
\hline Owner & 4 & 6.90 & 73 & 92,40 \\
\hline Owner of Certification & 55 & 94.82 & 28 & 35,44 \\
\hline Training & 55 & 94.82 & 16 & 20.25 \\
\hline Collaboration with academia & 18 & 31.04 & 1 & 1.27 \\
\hline \multicolumn{5}{|l|}{ Firm Size } \\
\hline Small (0-49 employee) & 8 & 10.52 & 68 & 89.48 \\
\hline Medium (50-249) & 42 & 79.25 & 11 & 20.75 \\
\hline Big (250 and more) & 8 & 100 & - & - \\
\hline Total & 58 & 42.34 & 79 & 57.66 \\
\hline Average Employee & \multicolumn{2}{|c|}{147.01} & \multicolumn{2}{|c|}{30.50} \\
\hline $\begin{array}{l}\text { Average Investment (Percentage Share in } \\
\text { Annual Revenue) }\end{array}$ & \multicolumn{2}{|c|}{21.69} & \multicolumn{2}{|c|}{13.26} \\
\hline Average Yearly Occupancy Rate & \multicolumn{2}{|c|}{81.63} & \multicolumn{2}{|c|}{68.73} \\
\hline Average age & \multicolumn{2}{|c|}{12.47} & \multicolumn{2}{|c|}{9.87} \\
\hline
\end{tabular}

Table 1. Questionnaire Results, Descriptive Statistics 
and zero otherwise) and continuous variable of age of the firm. All variables are expected to have a positive impact on the probability of innovation of the firm, except for variables of non-certified and age of the firm. The coefficient on non-certified is expected to be negative indicating that if the firm does not have any kind of certification, then its probability to innovate decreases. A priori, the effect of the age of the firm on innovation is not known as argued above. Table 2 presents the estimation results.

Estimation results are consistent with the expectations and all coefficients are significant at conventional levels. Wald tests indicate that both regressions are significant as a whole and Pseudo $\mathrm{R}^{2}$ is respectively high indicating that our models have a good predictive power. We also performed a test to determine whether there is any misspecification in our model and the Link test indicates that there is none.
The estimation results indicate that as the firms' investment and its capacity utilization increase, the probability of innovation increases as well. Firms who allocate budget to new investments (such as new technologies and equipment, or update old technologies and equipment) have higher probability to innovate. Further, as occupancy rate increases, the probability to innovate increases as well. This finding is similar to that of Orfila-Sintes et al. (2005). Firms which hire a professional manager are more inclined to innovate. Professional management is very important in the introduction of innovation as suggested by our study and others (Sundbo et al. 2007; Kumar et al., 2008).

If the firm does not have any certification, its probability of innovating decreases compared to other firms which have any kind of certification. Hotels with any certifications are more inclined to innovate since they have to invest and adopt new

\begin{tabular}{|c|c|c|}
\hline Variables & Logit Coefficients & Probit Coefficients \\
\hline Investment & $\begin{array}{c}0.68 * * * \\
(0.21)\end{array}$ & $\begin{array}{c}0.38 * * * \\
(0.09)\end{array}$ \\
\hline Occupancy Rate & $\begin{array}{c}0.83^{* * *} \\
(0.21)\end{array}$ & $\begin{array}{c}0.46 * * * \\
(0.11)\end{array}$ \\
\hline Non-Certified & $\begin{array}{c}-9.61 * * * \\
(2.25)\end{array}$ & $\begin{array}{c}-5.49 * * * \\
(1.31)\end{array}$ \\
\hline Number of Employees & $\begin{array}{c}-0.15 * * * \\
(0.05)\end{array}$ & $\begin{array}{c}-0.09 * * * \\
(0.03)\end{array}$ \\
\hline (Number of Employees) $^{2}$ & $\begin{array}{c}0.0003^{* * *} \\
(0.0001)\end{array}$ & $\begin{array}{c}0.0002 * * * \\
(0.0001)\end{array}$ \\
\hline Training & $\begin{array}{c}15.67 * * * \\
(3.48)\end{array}$ & $\begin{array}{c}9.04 * * * \\
(2.09)\end{array}$ \\
\hline Professional Management & $\begin{array}{c}11.85^{* * *} \\
(2.79)\end{array}$ & $\begin{array}{c}6.66 * * * \\
(1.57)\end{array}$ \\
\hline Collaboration with Academia & $\begin{array}{c}4.3 * * * \\
(1.39)\end{array}$ & $\begin{array}{c}2.34 * * * \\
(0.79)\end{array}$ \\
\hline The age of firm & $\begin{array}{c}-0.58 * * \\
(0.27)\end{array}$ & $\begin{array}{c}-0.29 * * * \\
(0.09)\end{array}$ \\
\hline Constant & $\begin{array}{l}-82.18 \\
(21.15)\end{array}$ & $\begin{array}{c}-45.71 \\
(10.92)\end{array}$ \\
\hline Number of Observations & 134 & 134 \\
\hline Wald $\operatorname{chi}^{2}(9)$ & 23.65 & 31.2 \\
\hline Prob > chi & 0.0049 & 0.0003 \\
\hline Pseudo $\mathbf{R}^{2}$ & 0.8984 & 0.8972 \\
\hline Link Test & -0.007 & -0.011 \\
\hline
\end{tabular}

Figures in parenthesis are robust standard errors. *,**,*** refer significance level at $10 \%, 5 \%$, and $1 \%$ respectively.

Table 2. Logit and Probit Estimation Results 
procedures and requirements and while doing this, their probability to innovate increases. In the literature that we were able to reach, we could not find any study that specifically take certification into account while investigating the innovative behaviors of the accommodation sector. So it is not possible to compare our results with any other study.

The coefficient on training is positive and significant. Firms who trained their employees are more likely to innovate than others. Our finding is similar to that of Orfila-Sintes and Mattson (2009) and Chun-Yao et al (2008). Collaboration with academia is found to have a positive impact on the innovation probabilities of firms. We could not compare our results with any other study since we could not find any empirical investigation which specifically takes into account the effect of collaboration with academia on innovation performance of firms.

We find significant coefficients on size and size squared. As size increases, the probability to innovate decreases; however, once the threshold is achieved then an increase in size increases the probability of innovation. The sign on coefficients on size square indicates that the probability to innovate increases once the economies of scale are achieved. There is an indication that economies of scale might exist in the accommodation sector. Our findings indicate that there is a U-shape relationship between innovation probability and firm size.

As far as we know there is no study in the tourism literature that specifically takes into account non-linearity in innovation with respect to size; hence we could not compare our results with any other study in the tourism literature. However, in other studies it is found that larger firms are more innovative than the small ones (Hjalager, 2002; Jacob et al., 2003; Jacob and Groizard, 2007; Sundbo et al., 2007).

Our empirical findings indicate that as firms get older, the probability to innovate decreases. This result is confirmed by both models. This finding suggests that aged firms may show resistance to innovation or be unable to change their managerial positions or renew facilities according to a more demanding environment. More research is needed in this area.

\section{Concluding remarks}

This study investigated the role of human capital and collaboration with academia on innovation performance of hospitality firms by employing self- generated survey data obtained from the district of Mugla which is the second largest tourist attraction in Turkey. The econometric logit and probit model is estimated by utilizing the survey data. Estimation results indicate that besides conventional factors of innovation in the hospitality sector such as investment, management type and occupancy rate, human capital and collaboration with academia are important determinant factors of innovation performance of firms as well.

With the increasing competition around the globe, innovation becomes the center of attention. Firms and enterprises should be aware of the potentials for innovation, such as new business models, additional investment for not only renewal of the existing equipment but also new equipment and installations. Weiermair (2006) claims that the challenge for the future in the tourism sector is "to provide increased value for money either through innovation-driven changes in production and marketing processes that reduce costs or product changes that offer more varied tourism experiences for quality conscious customers".

Innovation-oriented tourism policy is needed to have sustainable growth for the economy as a whole and for the tourism firms. These policies in the hospitality sector should aim to promote first the quality of education. The problem in the tourism sector is that it usually attracts staff with little or no industry-relevant training with a high labor turnover at a low salaries and non-standard working conditions. There is not widespread dedicated career system in the traditional sense in the tourism sector (Hjalager, 2002). To overcome these problems, investment in human capital in the tourism sector is severely needed. As Blake et al. (2006) suggest, government policy for training can overcome the problem of underinvestment of human capital by businesses. Second, collaboration with academia should be promoted. Our empirical evidence supports the view that university-sector relation is important for innovation performance, and thus for the overall performance of firms in tourism.

Sundbo et al. (2007) claim that larger firms are able to employ people with more education, thus increasing the possibility of innovation. They suggest that policy makers should give more importance to education and managerial professionalism in the tourism industry and promote the use of IT in the tourist industry. They claim that "destination building based on large-scale tourism firms may sustain innovative and thus competitive tourist destina- 
tions." (p. 104).

Our findings suggest that increasing innovative activity of firms can involve several policy actions. These are; i) investment in both human and physical capital, ii) promotion of collaboration with academia, professional management and ownership of certification by firms, iii) taking measures to increase capacity utilization of firms and iv) promotion of larger firms so that economies of scale can be achieved. All these can be achieved by the stimulating, coordinating and promoting role of the state.

\section{References}

Barras, R.

1986 Towards a theory of innovation in services. $R e$ search Policy, 15(4): 161-173.

Blake, A., Sinclair, M. T. and Soria, J. A. C.

2006 Tourism productivity: Evidence from the United Kingdom. Annals of Tourism Research, 33(4): 1099-1120.

Chun-Yao, T., Hui-Yueh, K. and Shou-Shiung, C.

2008 Configuration of innovation and performance in the service industry: Evidence from the Taiwanese hotel industry. The Service Industries Journal, 28(7): 1015-1028.

Decelle , X.

2006 A dynamic conceptual approach to innovation in tourism. In: Innovation and Growth in Tourism (pp. 85-106). Paris: OECD.

Drejer, I.

2004 Identifying innovation in surveys of services: A Schumpeterian perspective. Research Policy, 33: 551-562.

Hjalager, A. M.

1997 Innovation patterns in sustainable tourism: An analytical typology. Tourism Management, 18 (1): $35-41$.

Hjalager, A. M.

2002 Repairing innovation defectiveness in tourism. Tourism Management, 23: 465-474.

Hjalager, A. M.

2010 A review of innovation research in tourism. Tourism Management, 31: 1-12.

Hughes, A. and Wood, E.

2000 Rethinking innovation comparisons between manufacturing and services: The experience of the CBR SME Surveys in the UK. In J. S. Metcalfe, I. Miles (eds.), Innovation Systems in the Service Economy Measurement and Case Study Analysis (pp. 105-124). Boston: Kluwer Academic Publishers.
Jacob, M., Tintore, J., Aguilo, E., Bravo, A. and Mulet, J.

2003 Innovation in the tourism sector: Results from a pilot study in the Balearic Islands. Tourism Economics, 9(3): 279-295.

Jacob, M. and Groizard, J. L.

2007 Technology transfer and multinationals: The case of Balearic hotel chains' investments in two developing economies. Tourism Management, 28: 976-992.

Keller, P.

2006 Innovation and tourism policy. In: Innovation and Growth in Tourism (pp.17-40), OECD: Paris.

Kumar, U., Kumar, V. and Grosbois, D.

2008 Development of technological capability by Cuban hospitality organizations. Journal of Hospitality Management, 27(1): 12-22.

Orfila-Sintes, F., Crespi-Cladera, R. and MartinezRos, E.

2005 Innovation activity in the hotel industry: Evidence from Balearic Islands. Tourism Management, 26: 851-865.

Orfila-Sintes, F. and Mattsson, J.

2009 Innovation behavior in the hotel industry. Omega, 37: 380-394.

Ottenbacher, M., Shaw, V. and Lockwood, A.

2006 An investigation of the factors affecting innovation performance in chain and independent hotels. Journal of Quality Assurance in Hospitality and Tourism, 6(3/4): 113-128.

Pires, C., P., Sarker, S. and Carvalho, L.

2008 Innovation in services-how different from manufacturing? The Service Journal, 28(10): 1339-1356.

Schumpeter, J. A.

1934 The Theory of Economic Development: An Inquiry into Profits, Capital, Credit, Interest and the Business Cycle. Cambridge, MA: Harvard University Press.

Sirilli, G. and Evangelista R.

1998 Technological innovation in services and manufacturing: Results from Italian surveys. Research Policy, 27: 882-899.

Sundbo, J.

1997 Management of innovation in services. The Service Industries Journal, 17(3): 432-455.

Sundbo, J.

1998 The Organization of Innovation in Services. Aldershot: Edward Elgar.

Sundbo, J., Orfila-Sintes, F. and Sorensen, F.

2007 The innovative behavior of tourism firms 
comparative studies of Denmark and Spain. Research Policy, 36: 88-106.

Tamura, S., Sheehan, J., Martinez, C. and Kergroach, S.

2005 Promoting innovation in services. In Enhancing the Performance of the Service Sector. OECD/RIETI, 133-177.

Weiermair, K.

2006 Product improvement or innovation: What is the key to success in tourism? In Innovation and Growth in Tourism. OECD.

\section{Notes}

1 There are 5 parts and 44 questions in the questionnaire. The first part aimed to identify basic information about hotels. The second part was designed to address the list and description of novelties or improvements. The third part aimed to identify characterization of innovation activities. The fourth and fifth part includes questions concerning human capital characteristics of firms and collaboration with academia.

2 Following the literature and definition of in-novation in service sector of OECD, we defined technological improvement and innovation and ask whether firm is engaged with any kind of these activities. If the answer is yes then we categorize these firms as innovating firms.

Recibido:

$15 / 02 / 2011$

Reenviado:

Sometido a evaluación por pares anónimos 